\title{
Development of the Alpha female character through habits based on Islamic education perspective
}

\author{
Ayu Fitria Nur Utami ${ }^{*}$ (1) https://orcid.org/0000-0001-5080-9199 \\ Yusup Rohmadi1 ${ }^{1}$ https://orcid.org/0000-0001-7633-2296 \\ ${ }^{1}$ UIN Raden Mas Said Surakarta, Indonesia
}

\begin{abstract}
When women reach adolescence, they undergo psychological changes that affect their identity; thus, a woman must be able to instill positive values in order to develop a strong sense of selfworth. A woman with an Alpha female figure is depicted in the picture. This study aims to explain the figure of the Alpha female in Islamic female characters, as well as to examine the steps for a Muslim teenager to grow as such an Alpha female through habits. The paper analysis method was used in this study, and the documents used by the researcher were research materials from Henry's book; The Girl Guide, and Felix y Siauw's; How to Master your Habits. A descriptive qualitative analysis was used to analyze the data. The results of the study indicate that developing the Alpha female through habits in the context of Islamic education can be accomplished by first, providing motivation to improve. Second, training and repetition of activities related to alpha female creation, such as alpha friend, alpha student, professional alpha, and alpha look. The Alpha Female required a third time and consistency to evolve. The fourth is to be an expert, namely being able to form habits, control habits, and dominate habits. The results of this study contribute to the material for a woman in an effort for better selfdevelopment.
\end{abstract}

\section{ARTICLE INFO}

Keywords:

alpha female; habits; Islamic

education

\section{Article History:}

Received: 01 March 2021

Revised: 10 October 2021

Accepted: 17 November 2021

Published: 30 December 2021

\section{How to Cite in APA Style:}

Utami, A. F. N. \& Rohmadi, Y. (2021). Development of the Alpha female character through habits based on Islamic education perspective. Journal of Educational Management and Instruction, 1(2), 102-110.

\section{Introduction}

When a woman reaches adolescence, she goes through a lot of biological and psychological changes. Women in their teenage years often go through a period of social and economic change and dependency helping them to become more self-reliant. A woman will struggle to deal with the changes that arise during this period and it is important for a young woman to be able to accept self-development in order to understand her identity as a developmental task. In addition, the characteristics will also emphasize the importance of relationships with people around them.

As a result of some of the reforms that has taken place. The psychological aspect of the transition becomes the most important subject, despite the fact that the psychological aspect plays an important role in stating one's identity as a task in one's development towards adolescence. If a teen instills negative values in his or her identity, he or she will experience emotional instability, interpersonal issues, academic failure, dependency, secret resistance, depression anxiety, feelings of loneliness, not being loved, a lack of ability to solve problems and make decisions, and a difficult time accepting criticism. Furthermore, as teenagers grow older, they will face problems in the form of demands from their surroundings, causing the issue to have an effect on their self-esteem (Kamila \& Mukhlis, 2013).

Self-esteem is a person's evaluation of his or her own self-image in different areas of life. Self-esteem is a major issue in youth, according to many reports. According to 
many studies, when a person is in the adolescent phase, his self-esteem drops and he has a negative view of himself. These results indicate that self-esteem is a significant problem. Since low self-esteem is linked to a plethora of issues in their lives. So, in order to form a confident character, a woman must be able to cultivate The Alpha female inside herself (Simpson-scott, 2009).

The Alpha female is a multi-role figure of a woman who dares to appear superior in her community while still handling her domestic role as a woman, which includes managing the household and caring for children (Manampiring, 2016). There have been many Alpha females in Islam's culture. The praiseworthy image of a woman, according to the Qur'an, is a woman who is independent, political, and vital in what she faces, and who has strong dignity and freedom in making personal choices that are believed to be real. Ratu Bulqis, Khadijah binti khuwalid Maryam, 'Asiyah, and others are alpha female figures revered by Muslims.

According to the above explanation, it is critical to create an invention in order to develop the Alpha female in an individual, namely through habits. Women will develop a positive self-perception as a result of these developments, allowing them to develop an autonomous, optimistic, and assertive attitude toward themselves and others.

Habits are everything that is carried out continuously so that it becomes a part of a human being (Siaw, 2018). According to Islamic teachings, Muslims should always practice good deeds, even if they are small habits, and if they are practiced consistently, they will help to avoid bad habits. Islam teaches that people have the ability to stand firm in their beliefs. As a result, Islamic teachings are consistent with the concept of good behaviors. It is certain that a woman with good habits would be more prosperous in life. Positive behaviors are required for a Muslim adolescent to cultivate the Alpha female inside them. This is due to the fact that many youth have a low perception of themselves, leading to thoughts such as pessimism, anti-social behavior, and an inability to consider other people's viewpoints (Refnadi, 2018). This will be a problem when they interact with other people.

From the explanation above, it shows that women possessing the alpha female will be more able to control themselves, compared to women who have not been able to develop an alpha female in themselves. If a woman is unable to cultivate the alpha female, she may develop apathy toward her surroundings. Habits are required to grow The Alpha female in order to achieve the ideal character.

According to Yunus (2017), who conducted a study titled the meaning of alpha female in female librarian: Building a Positive Image of Libraries through Female Librarians as Alpha Female, explains that the value of an alpha female figure for female librarians is supposed to increase the negative perception of the librarian, who is portrayed as an old woman with thick glasses who only has the job of sitting behind the library table protecting books. Thus, the figure of a librarian (female), a professional who has high self-confidence in presenting herself to society through her success and competencies, is the definition of alpha female in librarians.

According to Batubara (2015) who conducted a study entitled Pengembangan Karakter Jujur Melalui Pembiasaan, explained that habituation is critical in the learning process, especially in the development of actions. Individuals can continue to do good if they receive a favorable response from the environment. Honesty can be developed by behaviors, such as stimulus-response and reinforcement.

According to some studies, the writer believes that the creation of the alpha female is critical in the formation of a positive role model for a Muslim adolescent girl. The Alpha Female cannot be given instantly, particularly to those who are still learning. There are steps that must be completed in order to form an Alpha Female, which can be accomplished through Islamic habits. The author will investigate how the Alpha Female develops through habits in the context of Islamic education. This study aims to explain the figure of the alpha female in Muslim female figures and examine the steps for a 
Muslim teenager to build The Alpha Female through Habits (habituation) based on perspective of Islamic Education provided in the books Alpha Girl's Guide: Menjadi Cewek Smart, Independen, dan Anti Galau by Henry Manampiring and Felix y Siauw's book, How to Master Your Habits, and then to investigate the dominant ideology that exists in the text. The results of this study contribute to consideration for Muslim women in an effort for better self-development as well as a contribution of closure and add to the reference to the discourse analysis of non-fiction works, especially in selfdevelopment books.

\section{Method}

\section{Research context and participants}

This study aims to define the figure of the alpha female in Islamic female characters, and to examine how a Muslim adolescent can grow The Alpha Female through habits (habituation) in the context of Islamic education. To achieve this aim, researchers used a form of library research (library research), which data were collected through the investigation and investigation of a variety of literature through books and other sources that are relevant to the research undertaken (Sari \& Asmendri, 2018). Literacy is derived from book sources in this case, using a semiotics method. This semiotics describes how a main concept, research, or the true nature of a message works. The aim of literary semiotics in this case is to examine a sign that has a specific meaning. The tool used in this semiotic approach was a descriptive reduction; revealing visible facts through making careful observations to master a concept's definition, and performing an in-depth study of seeing The Alpha Female's development through habits in the context of Islamic education.

\section{Instrument and data collection}

This study's data instrument was compiled from a variety of sources and literature on research issues. In this analysis, we used two types of data; the first is primary data. Primary data is data coming from the original or first sources (Bajuri, 2013). The aim of this study is to develop the alpha female through habituation. Alpha Girl's Guide : Menjadi Cewek Smart, Independen, dan Anti Galau by Henry Manampiring, and Felix Y Siauw's book of How to Master Your Habits are the primary sources of information for this report. The second type of data is secondary data. Secondary data is information that can be used to supplement primary data. Secondary data is gathered from books, journals, papers, and previous studies through a literature review.

\section{Data analysis}

The data were analyzed by using interactive data analysis, consisted of three data analysis components: data reduction, data display, and conclusion. The research data that have been collected were then reduced. The next step was to display the data. The last step was to draw conclusions. The initial conclusions put forward are still temporary, and will change if no strong evidence is found to support it at the next data collection stage. But if the conclusions put forward at an early stage are supported by valid and consistent evidence when the researcher returns to the field of collecting data, then the conclusions put forward are credible conclusions (Nugroho, 2019).

\section{Results}

This section describes the results of data analysis obtained from primary data and secondary data. The presentation of the results is divided into two main themes, namely Alpha Female figures in Islamic female figures, and the steps of Development of The Alpha Female through Habits (habituation) based on Islamic education perspective. 


\section{The Alpha female figure in Islam}

Islam has raised the status of women. This can be seen by comparing the conditions of pre-Islamic and post-Islamic women. Islamic law does not make any distinction between men and women in its perspective (Zainul Muhibbin, 2011) . The perspective of the Qur'an also proves that Allah always places men and women in the same position; there is no discrimination in the Qur'an. The Qur'an teaches that the position of believers, both men and women, is equal before Allah, and they must obtain an equal status in the eyes of God, and both have been declared equal to receive Allah mercy (Hanapi, 2015).

The role of women in society and in the family is very broad, even by Rasulullah SAW. It reveals that the rise or fall of a nation is determined by its women. If women are good, the country will be saved. If women are not good, the country will be destroyed (Daulay, 2015). The alpha female is a woman who can be a driving force in her society and inspire others. She is a change agent, intelligent, self-assured, autonomous, and selfsufficient. Ideal women in Islam are active, creative, dynamic, respectful, and independent women who uphold their faith and morals. Several Islamic leaders own this figure (Mulia, 2014).

The first women who have the courage of faith and do not commit shirk, their moral dignity is maintained. The second is Queen Bulqis (queen of the kingdom of Saba'). A woman who is wise in making decisions and having political independence (Al-istiqlal al-siyasah). The third women who have economic independence (al-istiqlal al-iqtishadi) are like the figure of Rosulullah's wife, Khodijah and the husbandry manager in the story of Prophet Musa in the Madya region. The forth is 'Asiyah binti Muzahim, a woman who has strong faith and independence when consistent with her choice (Al-istqlal Alsyakshi) whose truth is believed. The fifth is Maryam binti imran, a woman who always maintains her chastity, is patient and believes the truth in herself and opposes the opinions of others.

\section{Development of The Alpha female through habits (habituation) based on Islamic education perspective}

Habituation encourages and provides space for humans to directly apply theories, so if they are used frequently, heavy theories become easy for humans (Syafri, 2014). This habit is based on experience, because habit is practice. The essence of habit is repetition. Habituation places humans as something special, which can save strength, because it will become an inherent and spontaneous habit, so that these activities can be carried out in every job (Ahsanulkhaq, 2019).

The purpose of a habit is to help a person change their existing attitude and develop a new habit that is more appropriate and positive and can change their lives for the better (Syah, 2016). In an effort to develop The Alpha Female, it takes good habits that are carried out repeatedly. In his book, Felix Y Siaw explains how to form good habits, encompassing: (Siaw, 2018)

To have motivation, if a man wants to do something, then he must know what motivates him to carry out the action, and the purpose for him doing that action is to attract him. If a person knows the motivation he wants to form, he will be more enthusiastic in doing it because basically everything needs a goal to be achieved.

To practice and repetition, practice serves as a determination of the activities that will be carried out according to the goal or not while the repetition will help to complete it.

To have time, after a person has been able to train and repeat activities to form his skills, then the next thing to do are determine how long he has to repeat it.

To be an expert, when someone has done training and repetition, he must also be able to truly master the skills and be able to provide benefits to himself and others. 


\section{Discussion}

\section{The Alpha female figure in Islam}

Mulia (Mulia, 2014) in her book entitled The Glory of Women in Islam explains that the figure of a woman in the Qur'an is described as an ideal and independent woman, but her faith and morals can still be maintained. Al-Qur'an has the ideal characteristics of a Muslim woman such as:

First, a woman who has strong faith and does not commit shirk. She is also maintained in her moral dignity by not lying, not stealing, not committing adultery and not neglecting children. As explained in QS Hud verse 72

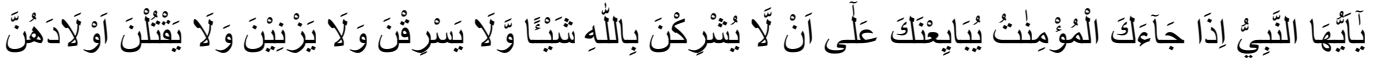

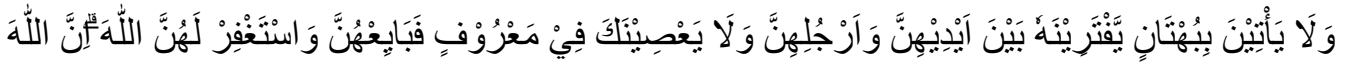$$
\text { غَفُوْرٌ رََّحِيْمِ }
$$

"O Prophet, when women believe come to you to make a pledge (allegiance) that they will not associate anything with Allah, will not steal, will not commit adultery, will not kill their children, will not commit lies that they inventive between their hands and feet) and will not disobey you in good affairs, accept their allegiance and ask Allah for their forgiveness. Allah is Forgiving, Most Merciful "

The wife of Prophet Ibrahim is an example of the story of the Prophet's wife told in the Qur'an. Sarah, who has been married to Prophet Ibrahim for many years but has never given birth to a child. In modesty, she acquiesce her husband remarried Hajar in the hopes of having a child. Sarah was the first woman to believe in her husband's calling.

The two women who are wise in decision-making and have political independence (al-istiqlal al-siyasah) are similar to Queen Bilqis, the queen of the kingdom of Saba (' arsyun 'azhim). As stated in verse 23 of Qs An-Naml:

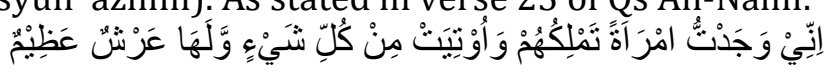

"In fact I found a woman who rules them (residents of the land of Saba '). She is

blessed with everything and has a great throne".

The story of Queen Bilqis bin Sharahil, a powerful, intelligent, imaginative, and diplomatic woman who became the number one of human being in a superpower country named Saba because she sat on a large throne, is explicitly stated in the verse. Meanwhile, some scholars argue that this story does not imply validity in terms of the legality of women as leaders, it is undeniably editorial-empirically true that the Qur'an records a woman who engages in political action and control (Fathurrosyid, 2013).

The three women who have economic independence (al-istiqlal al-iqtishadi) are like the figure of Rosulullah's wife, Khodijah and the husbandry manager in the story of Prophet Musa in the Madya region. As stated in QS Al-Qhasas verse 23:

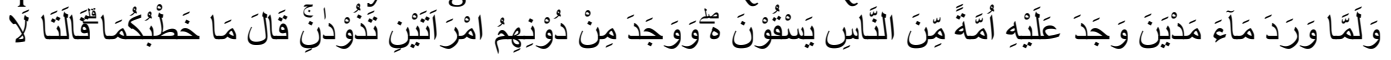

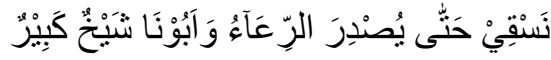

When he arrived at the source of water in the country of Madyan, he found a group of people who were giving drink (livestock) and he found behind them two women were driving (his livestock from the water source). He (Moses) said, "What do you mean (do that)?" The two (women) replied, "We cannot give (our livestock) 
anything to drink until the shepherds return (the livestock), while our father is an old man."

The story of two women (career women) who have to give their friends a drink is told in the verse above. Watering livestock is a task that necessitates extra strength and is thus associated with men's jobs. When the Prophet Musa entered the city of Madyan, he found two women holding their cattle and keeping them away from the crowd of shepherds who wanted to give their backs a drink so they wouldn't overcrowd and mix with them (Darlis, 2015).

The four women who have firm faith and independence in making personal choices (Al-istiqlal al-syakhshi) whose truth is believed to be true, such as the wife of the pharaoh named 'Aisyah Binti Muzamin who strongly rejects the injustice of Qs Al-Tahrim verse 11.

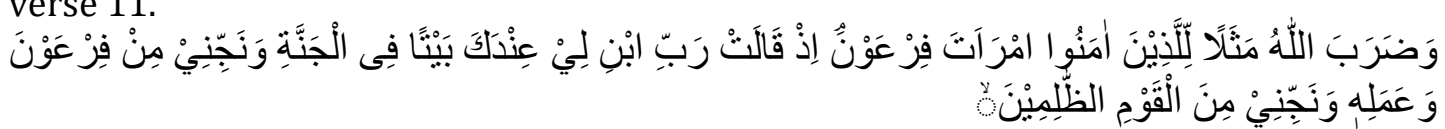

"Allah also made a parable for those who believe, namely the wife of Pharaoh, when he said," O my Lord, wake up for me by your side a house in heaven, save me from Pharaoh and his deeds, and save me from the wrongdoers. "

Fir'aun's wife (Asyiah) is a strong faith woman. Asiyah, on the other hand, did not believe that Fir'aun was God when her husband acknowledged that he was God. Asiyah is unafraid, despite the fact that her husband has absolute control. She also believed the idea that there is only one God, Allah SWT. She traded the pleasures of life and the opulence of the world's palaces for the palaces of heaven, knowing that this was where the eternal return lay.

Fifth, women who uphold self-purity, such as Maryam bint Imran, the mother of Prophet Isa (as), is willing to take a stand against many people's opinions because they believe theirs are right. Surah At-Tahrim 12 explains this.

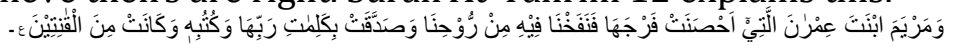

"Likewise, Maryam, the daughter of Imran, who keeps her honor, then We blow into her womb a part of Our spirit (creation), and who confirms the words of her Lord and His books, as well as those who are obedient."

Maryam always maintained her chastity, filled her time with sincere devotion to Allah, which in the end, because of her faith, received the mandate to protect and care for Allah's lover, Isa the son of Maryam. Therefore her honor lies in holiness, not in her beauty. From the story of Maryam, a woman who always keeps her chaste, wholeheartedly devotes her heart to her Lord, and maintains her trust with love and will always give birth to superior generations (Supriyadi, 2018).

\section{The Alpha Female Development Review through Habits (habituation) based on Islamic education perspective}

A good habit is needed with serious effort, even though it only does a small thing, it must be carried out consistently. Islam strongly encourages its followers to always get used to positive actions in their life. This is explained in the hadith narrated by Imam Muslim:

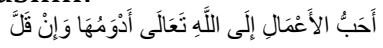

"The practice that is most loved by Allah Ta'ala is a continuous practice even though it is a little" (Imam Muslim)

Thus, it is clear that the principle of habits is in line with the principle of Islamic education. Felix Y Siaw in his book, How to master your habits (Siaw, 2018), explains that in order to start the development of a better self, what he wants to emphasize is that 
there is no need to think about what one's current initial position is. A person can become whatever or master any skill he wants if he really wants to, by forming habits.

In an effort to develop The Alpha Female, it takes good habits carried out repeatedly. In his book Felix Y siaw explains how to form good habits.

The first is motivation. If man wants to do something, then he must know what motivates him to carry out the action, and the purpose for him doing that action is to attract him. If a person knows the motivation he wants to form, he will be more enthusiastic in doing it because basically everything needs a goal to be achieved. In order to know the motivation that existed in us before, we must know very well what habits we want to form, through this we will be more motivated to achieve them. Life will be more interesting because there is something that is pursued or aimed at in life, so that life does not become a routine which found. Forming habits is the same as it requires clarity of purpose. If someone already knows the goals to be achieved, the greater the attraction will be generated. The clearer we want in the future, the greater the attractiveness to carry out an activity. Like a woman who has great motivation and vision to be able to form the Alpha female in her, she will always try to carry out activities that can continuously develop her skills. Apart from having a strong attraction, motivation also requires reasons for carrying out these activities or activities, when a person does not have a strong enough reason to do something, then he will continually postpone it, and even though he has a reason for actions will be postponed by him until he believes in that reason.

The second, after knowing the motivation in oneself, the next thing is Practice (exercise) and Repetition. If it is likened that habituation is the result of heredity, the father is practice and the mother is repetition. When the two meet, it is directed and controlled, it will certainly give birth to good habituation and form a main character in humans. Practice or exercise serves to determine whether the activity to be carried out is correct or not, right on target or not, while repeat or repetition will improve it. "Practice makes right, repetition makes perfect".

Continuous practice is very necessary so that activity can be carried out with the correct technique. Because if an activity is carried out in a wrong manner, then habits that are formed and vice versa are also wrong. What is very influential in the development of habits is activities repetition that gives life to habits. With repetition, we will instill a memory in the body, so that other memories will be executed automatically under certain conditions.

In his book Henry Manampiring explains the efforts to develop the alpha female practice and repetition that need to be done (Manampiring, 2016). The first is interacting with other people (the alpha friend), namely by following useful organizations to form expertise in surah Al-Maidah verse 2 which reveals

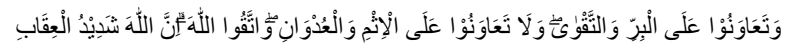

"And help you in (doing) virtue and piety, and do not help in sin and enmity."

The second is having awareness to learn (Alpha Student). Alpha Female sees the importance of education as a provision when she can live independently. With education, he can work and be financially independent (Manampiring, 2016). When having a family, women can also choose not to work, but women who have higher education as the first source of education for their children, look after their families at home, and help with all the needs of their husbands. Third, traininh soft skills (The Alpha Professional), if a woman is going to enter the world of work, what she has to do is to train her skills, namely having the courage to speak in front of a crowd but must have clarity in opinion, ability to adapt, as a listener who are good, and are not afraid to ask questions if 
something is not yet known. The last taking care of themselves (the alpha Look), the importance of women to be able to take care of themselves inside and outside, be it health, facial care, or in clothes. For example exercising, wearing appropriate clothing in all conditions because basically inner beauty is not enough to support it from the outside.

The third is time, after having the motivation to carry out activities repeatedly, the next step is to determine the time. Some scientists and researchers argue that it takes a man 21 days to practice a new habit, some think 28-30 days, and some even think 40 days. Felix gives a natural example, namely the implementation of fasting in the month of Ramadan which is held for 30 days. In fact, fasting is a development of new habits for Muslims. Often we feel uncomfortable mentally or physically at the beginning of fasting, the stomach feels sick, and the head becomes dizzy. But over time, after fasting for 30 days, the body begins to get used to the rhythm of the fasting month diet. So the new habits have been formed. Although habits will become more solid over time, 30 days or 1 month is the minimum limit for new habits to be formed. At least this is a limitation for forming habits. In simple terms, to form new habits, one must consistently practice and repetition for 30 consecutive days, without missing a day. Because basically habits means habituation, and habituation requires consistency. So in this case practice and repetition to develop the alpha female must be carried out consistently and continuously so that these habits can be carried out by reflection from oneself.

The fourth is to be an expert. Of course, a Muslim will not be satisfied with just forming habits. However, one must develop the habituation to become an expert (specialist expertise).

Expert means really mastering one skill. Not only mastering one skill, an expert is able to provide benefits not only for him but also for others and make himself a role model. Few among humans are able to get into the special and make it a habit. But there are even fewer people who are able to shape habits to become expertise. An expertise is not only able to shape habits and control habits, but also to master habits. So in this case a Muslim woman who wants to develop an alpha female within herself must be able to master skills that have been accustomed to and can benefit many people.

\section{Conclusion}

The aim of this research is to define the figure of the alpha female in Islamic female characters, and to examine the steps for a Muslim teenager to grow The Alpha Female through Habits (habituation) in the context of Islamic Education, as described in Henry Manampiring's book of Alpha Girl's Guide: Menjadi Cewek Smart, Independen, dan Anti Galau and Felix's Y Siauw book of How to Master Your Habits. The literature review approach was used in this analysis, with books and journals serving as data sources. The findings reveal that the development of female alpha is a habit that is consistent with Islamic education values. The number of Islamic figures with Alpha female figures demonstrates this. It is also known that the development of Alpha female through habituation can be carried out with motivation, namely developing the alpha female, training and repeating activities related to the development of the alpha female, namely the alpha friend, the alpha student, the professional alpha and the alpha look. Then the time is needed and consistency to develop The Alpha Female in a woman. Cultivating the habit offers several advantages in the self-improvement process. Apart from its strengths, there are several challenges, namely the lack of secondary data sources to support this research. The results of this study contribute to material consideration for a Muslim woman in an effort for better self-development. Finally, the researcher claims that a Muslim woman must always believe in instilling good habits in her in order to grow alpha female. The Alpha Female as a character-building process, according to a researcher's suggestion, should be discussed by a larger number of researchers. 


\section{References}

Ahsanulkhaq, M. (2019). Membentuk Karakter Religius Peserta Didik Melalui Metode Pembiasaan. Jurnal Prakarsa Paedagogia, 2(1), 21-33.

Bajuri, D. (2013). Analisis Kualitas Pelayanan Publik Perangkat Desa Pagandon Kecamatan Kadipaten Kabupaten Majalengka. Jurnal Ilmu Administrasi Negara, 6(1), 145-170.

Batubara, J. (2015). Pengembangan Karakter Jujur Melalui Pembiasaan. Jurnal Konseling Dan Pendidikan, 3(2), 1-6.

Darlis. (2015). Feminisme Qur'ani : Tafsur ayat wanita karir. Musawa, 7(2), 183-206.

Daulay, N. (2015). Perspektif Islam dan Psikologi. Al-Tahrir, 15(2), 263-282.

Fathurrosyid. (2013). Ratu Balqis dalam Narasi Semiotika al- Qur'an. Palastren: Jurnal Studi Genger, Vol. 6, No(Semiotika al-Qur'an), 245-276. http://journal.stainkudus.ac.id/index.php/Palastren/article/view/986/899

Hanapi, A. (2015). Peran Perempuan dalam Islam. Pusat Jurnal UIN Ar-Raniry, 1(1), 1526.

Ismi Isnani Kamila, \& Mukhlis. (2013). Perbedaan Harga Diri (Self Esteem) Remaja Ditinjau dari Keberadaan Ayah. Jurnal Psikologi UIN Sultan Syarif Kasim Riau, 9(Desember), 100-112.

Manampiring, H. (2016). Alpha Girl's Guide: Menjadi Cewek Smart, Independen, dan Anti Galau, (4th ed.). Gagas Media.

Mulia, M. (2014). Kemuliaan Perempuan dalam Islam. PT Alex Media Komputindo.

Nugroho, A. (2019). Request Realizations of Indonesian Esp Lecturers. Celtic: A Journal of Culture, English Language Teaching, Literature and Linguistics, 6(1), 1-13.

Refnadi, R. (2018). Konsep self-esteem serta implikasinya pada siswa. Jurnal EDUCATIO: Jurnal Pendidikan Indonesia, 4(1), 16. https://doi.org/10.29210/120182133

Sari, M., \& Asmendri. (2018). Penelitian Kepustakaan (Library Research) Dalam Penelitian Pendidikan IPA, 15. https://ejournal.uinib.ac.id/jurnal/index.php/naturalscience/article/view/1555/ 1159

Siaw, F. (2018). How To Master Your Habits, (11th ed.). AlFatih Press.

Simpson-scott, L. (2009). Self Perceived Information Seeking Skiils and Self Esteem in Adolescents by Race and Gender. University of North Texas.

Sugiyono. (2015). Metode Penelitian Kombinasi. Alfabeta.

Supriyadi, T. (2018). Wacana Perempuan Dalam Perspektif Pendidikan Islam. Jurnal Sosioreligi, 16(1), 14-21.

Syafri. (2014). Pendidikan Karakter Berbasis Al-Qur'an. Rajawali Press.

Syah, M. (2016). Psikologigi Pendidikan dengan Pendidikan Baru. Remaja Rosdakarya.

Yunus, W. (2017). The Meaning of Alpha Female in Female Librarian: Building a Positive Image of Libraries through Female Librarians as Alpha Female. Humanus, 16(1), 50-58. https://doi.org/10.24036/jh.v16i1.7344

Zainul Muhibbin. (2011). Wanita dalam Islam. Jurnal Sosial Humoniora, 4(2), 109-120. 